\title{
Volatility of Common Protective Oxides in Water Vapor: Current Understanding and Unanswered Questions
}

\author{
Elizabeth Opila \\ NASA Glenn Research Center, Cleveland, Ohio, USA
}

\begin{abstract}
Many structural materials rely on the formation of chromia, silica, or alumina as a protective layer when exposed in high temperature oxidizing environments. Growth of these oxides provides a protective diffusion barrier which slows down further oxidation. In water vapor, however, each of these oxides can form volatile hydroxide species which remove the surface oxide, thus, lowering the protective capability of the oxide scale. This paper summarizes the current understanding of volatility of chromia, silica, and alumina in water vapor-containing combustion environments. In addition unanswered questions in each system are discussed.

It is well known that chromia scales volatilize in oxidizing environments to form $\mathrm{CrO}_{3}(\mathrm{~g})$. In water vapor, the very stable $\mathrm{CrO}_{2}(\mathrm{OH})_{2}(\mathrm{~g})$ species is formed which has a much higher partial pressure than $\mathrm{CrO}_{3}(\mathrm{~g})$. However, there are at least three sets of thermochemical data for this species which differ by as much as two orders of magnitude in predicted partial pressures of $\mathrm{CrO}_{2}(\mathrm{OH})_{2}(\mathrm{~g})$. Differences between these data sets have not yet been resolved.

Within the last ten years, the importance of silica volatility in combustion environments has been identified. Silica is known to react with water vapor to form $\mathrm{Si}(\mathrm{OH})_{4}(\mathrm{~g})$. Accurate thermodynamic data are available for this species. However, there are a number of unanswered questions in this system. First, at high temperatures $\left(>1300^{\circ} \mathrm{C}\right)$, there is evidence for $\mathrm{SiO}(\mathrm{OH})_{2}(\mathrm{~g})$ formation from silica and water vapor. However, available thermodynamic data for this species show large variations. Current work is underway to resolve this issue. Second, silica volatility rates in fuel-rich combustion environments are more rapid than predicted for $\mathrm{Si}(\mathrm{OH})_{4}(\mathrm{~g})$ formation alone. A third unanswered question is why silica volatility rates appear to differ depending on whether silica is formed on silicon carbide or silicon nitride in combustion environments. One possible explanation is that the silica volatility is the same, but differences in material temperature at a constant gas temperature result in apparent differences in volatility. Finally, at very high gas velocities silica is absent from the surface of silicon nitride, while recession rates are consistent with silica volatility by $\mathrm{Si}(\mathrm{OH})_{4}(\mathrm{~g})$ formation. Possible active oxidation-water vapor reaction mechanisms are discussed.

Alumina volatility in water vapor has also been recently observed, albeit at higher temperatures than chromia and even silica volatility. It is believed that the formation of $\mathrm{Al}(\mathrm{OH})_{3}(\mathrm{~g})$ is the primary volatilization reaction in combustion environments. The identity of this molecule has been proposed based on the observed water vapor pressure dependence of its formation. Preliminary results showing mass spectrometric identification of this species will be presented, but more definitive results are needed.

In conclusion, a comparison of the three systems shows that the partial pressures of volatile metal hydroxides formed in combustion environments decrease in magnitude in the following order: $\mathrm{CrO}_{2}(\mathrm{OH})_{2}(\mathrm{~g})>\mathrm{Si}(\mathrm{OH})_{4}(\mathrm{~g}), \mathrm{SiO}(\mathrm{OH})_{2}(\mathrm{~g})>\mathrm{Al}(\mathrm{OH})_{3}(\mathrm{~g})$.
\end{abstract}




\title{
Volatility of Common Protective Oxides in High-Temperature Water Vapor: Current Understanding and Unanswered Questions
}

\author{
Elizabeth J. Opila \\ NASA Glenn Research Center, Cleveland, OH 44135 USA, opila@nasa.gov
}

Keywords: volatility, water vapor, chromia, silica, alumina

\section{Introduction}

Many structural materials rely on the formation of chromia, silica, or alumina as a protective layer when exposed in high temperature oxidizing environments. The presence of these oxide layers provides a protective diffusion barrier which slows down further oxidation. In atmospheres containing water vapor, however, reactions to form volatile hydroxide species occur which remove the surface oxide, thus, lowering the protective capability of the oxide scale. This paper summarizes the current understanding of volatility of chromia, silica, and alumina in water vaporcontaining combustion environments. In addition unanswered questions in each system are discussed. These systems were reviewed in a previous publication [1]. The current paper represents an update on the considerable information learned in the past five years for these systems.

Volatility is defined here as material loss due to the formation of vapor species. Volatility of oxides in environments containing water vapor occurs by the following generalized reaction:

$$
\mathrm{MO}_{\mathrm{x}}+\mathrm{nH}_{2} \mathrm{O}(\mathrm{g})+\mathrm{mO}_{2}(\mathrm{~g})=\mathrm{MO}_{(\mathrm{x}+\mathrm{n}+2 \mathrm{~m})} \mathrm{H}_{(2 \mathrm{n})}(\mathrm{g}) \text {. }
$$

For the systems of interest, here, the specific volatilization reactions are:

$$
\begin{aligned}
& 1 / 2 \mathrm{Cr}_{2} \mathrm{O}_{3}+\mathrm{H}_{2} \mathrm{O}(\mathrm{g})+3 / 4 \mathrm{O}_{2}(\mathrm{~g})=\mathrm{CrO}_{2}(\mathrm{OH})_{2}(\mathrm{~g}) \\
& 1 / 2 \mathrm{Cr}_{2} \mathrm{O}_{3}+3 / 4 \mathrm{O}_{2}(\mathrm{~g})=\mathrm{CrO}_{3}(\mathrm{~g}) \\
& \mathrm{SiO}_{2}+2 \mathrm{H}_{2} \mathrm{O}(\mathrm{g})=\mathrm{Si}(\mathrm{OH})_{4}(\mathrm{~g}) \\
& \mathrm{SiO}_{2}+\mathrm{H}_{2} \mathrm{O}(\mathrm{g})=\mathrm{SiO}(\mathrm{OH})_{2}(\mathrm{~g}) \\
& \mathrm{SiO}_{2}+1 / 2 \mathrm{H}_{2} \mathrm{O}(\mathrm{g})=1 / 4 \mathrm{O}_{2}(\mathrm{~g})+\mathrm{SiO}(\mathrm{OH})(\mathrm{g}) \\
& 1 / 2 \mathrm{Al}_{2} \mathrm{O}_{3}+3 / 2 \mathrm{H}_{2} \mathrm{O}(\mathrm{g})=\mathrm{Al}(\mathrm{OH})_{3}(\mathrm{~g})
\end{aligned}
$$

For systems in which more than one volatilization reaction occurs, the reaction listed first is of primary interest for typical temperatures and water vapor partial pressures of industrial processes such as cooling, processing, and combustion applications. These reactions will be discussed in more detail in a following section.

\section{Kinetic Models}

This paper is concerned with the rate at which these volatilization reactions occur and the resulting consumption rate of underlying alloy or substrate. As a result, kinetic models which predict these rates are described next.

Tedmon oxidation/volatilization kinetics. At short times or for moderate oxide volatility, the oxide thickness is a function of both the parabolic oxidation rate, $\mathrm{k}_{\mathrm{p}}^{\prime}$, and the linear volatility rate, 
$\mathbf{k}_{1}^{\prime}$ (in units of length and time). Tedmon [2] has described oxidation/volatilization kinetics for chromia formers using the following relationship:

$$
\frac{d x}{d t}=\frac{k_{p}^{\prime}}{x}-k_{1}^{\prime}
$$

where $\mathrm{x}$ is the oxide thickness and $\mathrm{t}$ is exposure time. So that after integration the relationship between exposure time and oxide thickness can be expressed as:

$$
\mathrm{t}=\frac{\mathrm{k}_{\mathrm{p}}^{\prime}}{2 \mathrm{k}_{1}^{\prime 2}}\left[-\frac{2 \mathrm{k}_{1}^{\prime}}{\mathrm{k}_{\mathrm{p}}^{\prime}} \mathrm{x}-\ln \left(1-\frac{2 \mathrm{k}_{1}^{\prime}}{\mathrm{k}_{\mathrm{p}}^{\prime}} \mathrm{x}\right)\right]
$$

At long times or high volatility rates, a limiting oxide thickness, $x_{L}$, is developed which is given by:

$$
x_{L}=\frac{k_{p}^{\prime}}{2 k_{1}^{\prime}}
$$

Similar expressions can be developed for weight change and material recession. Thus the oxide thickness can be calculated if the rate constants are known.

Measured Oxidation Rate Constants. The oxidation rate constants are fairly well known for chromia, silica, and alumina formers. Chromia formation rates have been summarized by Hindam and Whittle [3]. There is large scatter in the oxidation rates, with those alloys containing reactive elements showing lower oxidation rates. The oxidation rate for chromium [4] and for chromiaforming alloys were found to be independent of oxygen partial pressure [3,5]. It has not been demonstrated that the oxidation rate is independent of water vapor partial pressure, although it is assumed to be true for the purposes of this paper.

The oxidation rates of $\mathrm{Si}[6], \mathrm{SiC}[7,8]$, and $\mathrm{Si}_{3} \mathrm{~N}_{4}[9]$ have been measured in water vapor. Silica formation rates are known to depend on the pressure of the oxidant as well as the type of oxidant. It is generally agreed that amorphous silica growth has a pressure dependence described by a power law exponent of one, or close to one, in both dry oxygen and water vapor $[6,8]$. The oxidation rate of silica formers is higher in water vapor than in dry oxygen since water vapor has a higher solubility in amorphous silica compared to oxygen [6].

Oxidation rates for alumina-formers have also been summarized by Hindam and Whittle [3]. The measured oxidation rate of $\mathrm{NiAl}[10]$ is considered here as representative for pure alumina formers. Alumina formation rates from an alloy have been shown to be independent of oxygen partial pressure [11]. Oxidation of alumina-forming alloys in the presence of water vapor does not change the kinetics unless the oxidation is cyclic in nature $[12,13]$.

Calculated Volatilization Rates. Volatilization rates can be calculated once the gas flow conditions over the oxide are defined. In many combustion environments, volatility is limited by transport of the volatile species away from the oxide surface through a gas boundary layer. To calculate the volatility for the boundary layer limited process, the equilibrium partial pressure of the volatile species must be known, or thermodynamic data must be available to calculate this pressure. Sources and limitations of the available thermodynamic data for the systems of interest in this paper are reported in the next section. Assuming volatility is limited by transport of the volatile species through a laminar boundary layer over an oxide of flat plate geometry, the following expression can be used to calculate the volatility rate $[14,15]$ : 


$$
\mathrm{k}_{\mathrm{l}}=0.664 \mathrm{Re}^{0.5} \mathrm{Sc}^{0.33} \frac{\mathrm{D} \rho}{\mathrm{L}}
$$

where $\mathrm{k}_{\mathrm{l}}$ is the flux of volatile species in $\mathrm{g} / \mathrm{cm}^{2} \mathrm{~h}, \mathrm{Re}$ is the dimensionless Reynold's number, $\mathrm{Sc}$ is the dimensionless Schmidt number, $\rho$ is the density of the volatile species in the laminar boundary layer, $D$ is the interdiffusion coefficient of the volatile species in the boundary layer and $L$ is the characteristic length of the flat plate. The interdiffusion coefficient is calculated using the Chapman Enskog equation [15] and the collision diameter and collision integral for the volatile species. These terms are generally not known and must be estimated from molecules of similar structure. The rate, $\mathrm{k}_{\mathrm{l}}$, is given in terms of weight loss of oxide in Eq. 11 and is related to the rate, $\mathrm{k}_{\mathrm{l}}$, given in terms of oxide recession in Eqs. 8 through 10 by the oxide density. Expanding the terms for $\mathrm{Re}, \mathrm{Sc}$, and $\rho$ results in the following expression:

$$
\mathrm{k}_{1}=0.664\left(\frac{\rho^{\prime} \mathrm{vL}}{\eta}\right)^{0.5}\left(\frac{\eta}{\rho^{\prime} \mathrm{D}}\right)^{0.33} \frac{\mathrm{D}}{\mathrm{L}} \frac{\mathrm{M}}{\mathrm{RT}} \mathrm{P}_{\mathrm{H}_{2} \mathrm{O}}^{\mathrm{n}} \mathrm{P}_{\mathrm{O}_{2}}^{\mathrm{m}} \exp \left(-\frac{\Delta \mathrm{G}}{\mathrm{RT}}\right)
$$

where $\rho$ ' is the gas density of the boundary layer, $v$ is the linear gas velocity, $\eta$ is the gas viscosity, $\mathrm{M}$ is the molecular weight of the volatile species, $R$ is the gas constant, $T$ is absolute temperature, $P$ is partial pressure of the noted species, $\mathrm{n}$ and $\mathrm{m}$ are the pressure dependence exponents for formation of one molecule of volatile hydroxide as in Eq. 1, $\Delta G$ is the free energy of reaction for formation of one molecule of hydroxide from the oxide and water vapor as in Eqs. 2 through 7, and all other terms have been previously defined. The activity of the solid oxide is assumed equal to one in Eq. 12. Simplifying Eq. 12 in terms of pressure (total pressure, P, as well as partial pressures of water vapor and oxygen), gas velocity and temperature results in the following relationship:

$$
\mathrm{k}_{1} \propto \mathrm{v}^{0.5} \frac{\mathrm{P}_{\mathrm{H}_{2} \mathrm{O}}^{\mathrm{n}} \mathrm{P}_{\mathrm{O}_{2}}^{\mathrm{m}}}{\mathrm{P}^{0.5}} \exp \left(-\frac{\Delta \mathrm{G}}{\mathrm{RT}}\right) \text {. }
$$

Here, the temperature dependencies of $\rho^{\prime}, \eta$, and $D$ are neglected, and a simple Arrhenius temperature dependence is assumed based on the free energy of reaction to form the volatile hydroxide. At high velocities, when flow is turbulent $\left(\operatorname{Re}>3 \times 10^{5}\right)$, the Reynolds number will have an exponent of 0.8 rather than 0.5 [14] and Eq. 12 should instead be simplified to:

$$
\mathrm{k}_{1} \propto v^{0.8} \frac{\mathrm{P}_{\mathrm{H}_{2} \mathrm{O}}^{\mathrm{n}} \mathrm{P}_{\mathrm{O}_{2}}^{\mathrm{m}}}{\mathrm{P}^{0.2}} \exp \left(-\frac{\Delta G}{\mathrm{RT}}\right) \text {. }
$$

The thermodynamic data needed for the calculation of volatility rates are described in the next section.

\section{Thermodynamic Data for Volatilization Reactions of Common Oxides}

The chromia-water vapor system. Three sets of thermodynamic data exist for the $\mathrm{CrO}_{2}(\mathrm{OH})_{2}(\mathrm{~g})$ species. Ebbinghaus [16] evaluated the data available in the literature up to 1993 . Gindorf et al. [17] have measured equilibrium partial pressures of $\mathrm{CrO}_{2}(\mathrm{OH})_{2}(\mathrm{~g})$ under typical solid oxide fuel 
cell cathode conditions using a transpiration technique. Finally, the IVTAN database [18] also contains data for this species, although the method of determination of these data is unknown to this author. Fig. 1 shows the disparity in calculated partial pressures of $\mathrm{CrO}_{2}(\mathrm{OH})_{2}$ based on the three data sets. Clearly, the differences in these data must be resolved before accurate predictions of chromia volatility can be made. $\mathrm{CrO}_{3}$ is also an important volatile species at low water contents and high temperatures. Data for this species from a number of sources are reliable $[16,19,20]$.

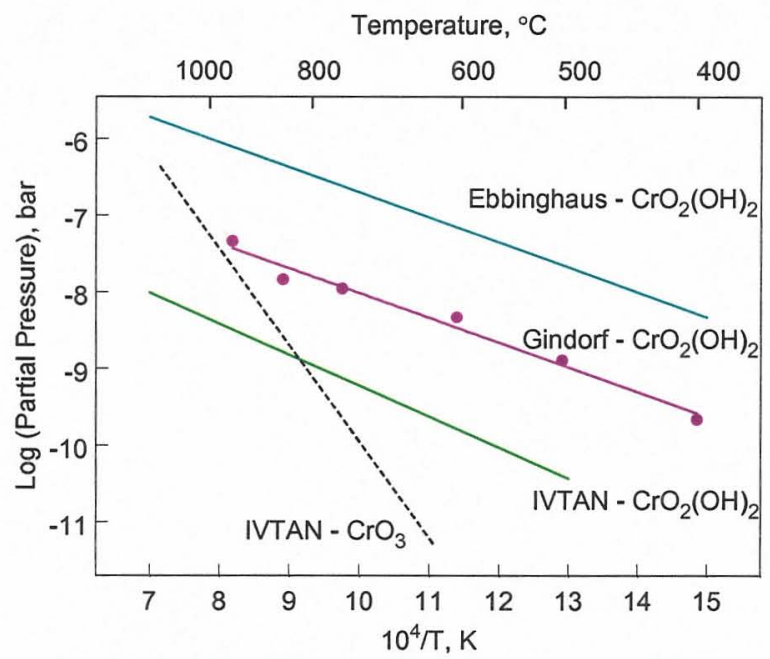

Fig. 1. Variation in calculated and measured pressures of $\mathrm{CrO}_{2}(\mathrm{OH})_{2}$ at 0.02 bar $\mathrm{H}_{2} \mathrm{O}$ and 0.21 bar $\mathrm{O}_{2}$ from three sources of thermodynamic data. Data for $\mathrm{CrO}_{3}$ are also shown. After Ref. [17].

The silica-water vapor system. Four sets of thermodynamic data are known for the $\mathrm{Si}(\mathrm{OH})_{4}(\mathrm{~g})$ species. In this case, the results are in good agreement. Krikorian [21] has estimated thermodynamic data based on partition functions and comparison to molecules of similar structure. Hashimoto [22] has measured equilibrium partial pressures of $\mathrm{Si}(\mathrm{OH})_{4}(\mathrm{~g})$ using a transpiration technique. Allendorf [23] has calculated thermodynamic data for this species using ab initio techniques. Finally, Copland et al. [24] have also measured equilibrium partial pressures of $\mathrm{Si}(\mathrm{OH})_{4}(\mathrm{~g})$ using a transpiration technique. Experimentally measured volatility rates $[25,26]$ are consistent with those rates calculated with Eqs. 13 and 14 and thermodynamic data for $\mathrm{Si}(\mathrm{OH})_{4}(\mathrm{~g})$. Other volatile $\mathrm{Si}-\mathrm{O}-\mathrm{H}$ species, such as $\mathrm{SiO}(\mathrm{OH})_{2}$ or $\mathrm{SiO}(\mathrm{OH})$ may be important at temperatures of $1400^{\circ} \mathrm{C}$ and higher. Thermodynamic data for these species are not considered reliable at this time.

The alumina-water vapor system. Three sets of data are available for the $\mathrm{Al}(\mathrm{OH})_{3}(\mathrm{~g})$ species. Gurvich et al. [20] have estimated thermodynamic data for this species based on partition functions and the structure of similar molecules. Hashimoto [22] has measured equilibrium partial pressures of $\mathrm{Al}(\mathrm{OH})_{3}(\mathrm{~g})$ from a mixture of calcium aluminate phases in water vapor using a transpiration technique. Finally, Allendorf [27] has calculated thermodynamic data for this species using ab initio techniques. All three sets of data are in fairly good agreement. Experimentally measured volatility rates [26,28] are consistent with those rates calculated with Eqs. 13 and 14 and thermodynamic data for $\mathrm{Al}(\mathrm{OH})_{3}(\mathrm{~g})$.

Comparison of chromia, silica, and alumina volatility. The relative rates of volatility for these oxides in water vapor can be assessed by comparing the equilibrium partial pressures of volatile species formed for a given set of conditions. Partial pressures for the primary volatile species in each oxide system have been calculated at 1 bar total pressure with equal amounts of oxygen and water vapor over the temperature range of 700 to $1500^{\circ} \mathrm{C}$. The comparison is shown in Fig. 2. Both the Ebbinghaus data [16] and the IVTAN [18] data for $\mathrm{CrO}_{2}(\mathrm{OH})_{2}(\mathrm{~g})$ are plotted to span the 
possible range of partial pressures for this species. $\mathrm{CrO}_{3}(\mathrm{~g})$ is neglected on this plot although it would become important under these conditions at temperatures greater than about $1100^{\circ} \mathrm{C}$ if the IVTAN values for $\mathrm{CrO}_{2}(\mathrm{OH})_{2}$ are correct. Gurvich data [20] are used for $\mathrm{Al}(\mathrm{OH})_{3}(\mathrm{~g})$ while Hashimoto's data [22] are used for $\mathrm{Si}(\mathrm{OH})_{4}$. Other Si-O-H species may become important at temperatures above $1400^{\circ} \mathrm{C}$.

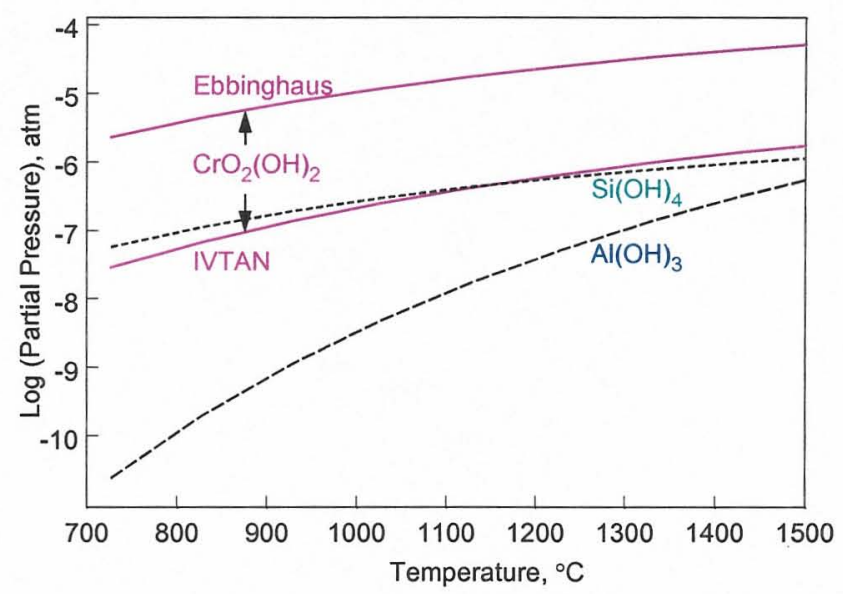

Fig. 2. Partial pressures of primary volatile species calculated for each oxide at one atm total pressure: 0.5 atm $\mathrm{O}_{2}, 0.5$ atm $\mathrm{H}_{2} \mathrm{O}$.

\section{Mapping Recession in a Combustion Environment as a Function of Total Pressure and Temperature}

Recession from steady state volatility can be determined as a function of pressure, temperature, and gas velocity as described by Eqs. 13 and 14. The velocity dependence of volatilization will be the same for all oxide systems in a given application since it depends only on the flow characteristics of the gaseous environment. In combustion environments, the oxygen partial pressure and water vapor partial pressure will scale with the total pressure. For fuel-lean hydrocarbon combustion (equivalence ratio $=0.6$ ), the oxygen partial pressure and water vapor partial will be about $8 \%$ and $9 \%$ respectively of the total pressure [29]. The pressure dependence can thus be simplified by replacing $\mathrm{P}_{\mathrm{H} 2 \mathrm{O}}$ by $0.09 \mathrm{P}_{\text {total }}$ and $\mathrm{P}_{\mathrm{O} 2}$ by $0.08 \mathrm{P}_{\text {total }}$ leaving one pressure term in Eqs. 13 and 14 . Variation of recession limited lifetime in combustion environments as a function of pressure and temperature can be visualized with the aid of a recession map as shown in Fig. 3 for $\mathrm{CrO}_{2}(\mathrm{OH})_{2}$ volatilization from chromia. Again, both the data of Ebbinghaus [16] and IVTAN [18] were used to calculate steady state volatility rates at a gas velocity of $50 \mathrm{~m} / \mathrm{s}$ as a function of temperature and total pressure in a combustion environment. The pressure-temperature conditions are plotted which show a recession of $250 \mu \mathrm{m}$ in 1,000 or 100 hours. The Ebbinghaus data are plotted for $100 \mathrm{~h}$, since $1000 \mathrm{~h}$ lifetimes could only be met for total pressures less than $1 \mathrm{~atm}$.

Fig. 4 compares oxide growth rates to oxide volatilization rates at 10 atm total pressure with a gas velocity of $50 \mathrm{~m} / \mathrm{sec}$. The oxidation curve is based on the expression for $\mathrm{k}_{\mathrm{p}}$ from Hindham and Whittle [3] for oxidation limited by transport of interstitial chromium ions. This rate is high relative to oxidation of chromia formers with reactive elements. Overall, the recession of chromia by volatility compared to recession from oxidation shows the relative importance of chromia volatility in combustion environments. Note that this comparison plot again neglects the effects of $\mathrm{CrO}_{3}(\mathrm{~g})$ formation which would be significant if the IVTAN data for $\mathrm{CrO}_{2}(\mathrm{OH})_{2}(\mathrm{~g})$ are correct. 
Similarly, recession maps are shown for silica and alumina in combustion environments in Figs. 5 and 6 respectively. One obvious result of these maps is that the alumina-water vapor system is much less sensitive to recession by volatility compared to the other oxide systems. Only at hightemperatures is alumina volatility an issue. Thus, alumina volatility has not been a problem for alumina-forming superalloys since their use temperature is below $1200^{\circ} \mathrm{C}$. Water-vapor induced volatility will be more of a concern at the higher use-temperatures proposed for alumina-based oxide/oxide composites and alumina-containing environmental barrier coatings.

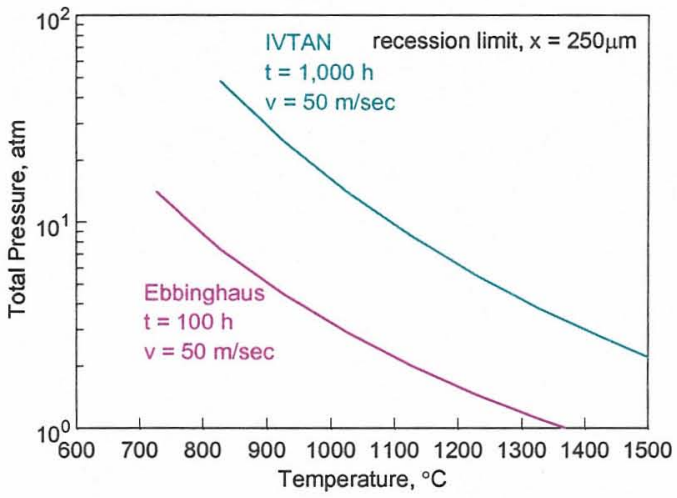

Fig. 3. Recession map for chromia volatility at a gas velocity of $50 \mathrm{~m} / \mathrm{sec}$. Pressures and temperatures below the curves represent conditions with acceptable recession rates.

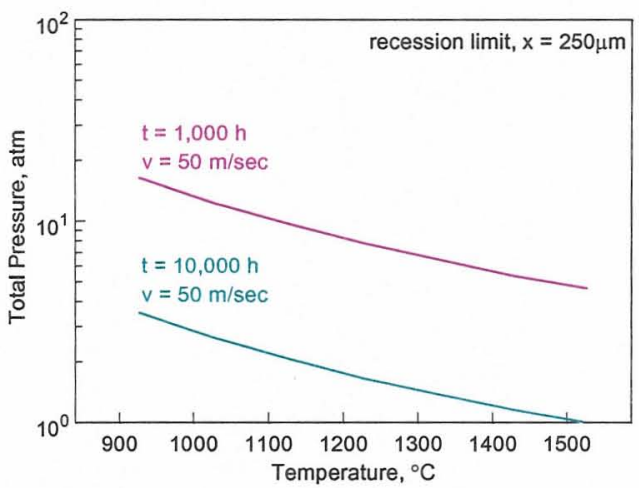

Fig. 5. Recession map for silica volatility at a gas velocity of $50 \mathrm{~m} / \mathrm{sec}$. Pressures and temperatures below the curves represent conditions with acceptable recession rates.

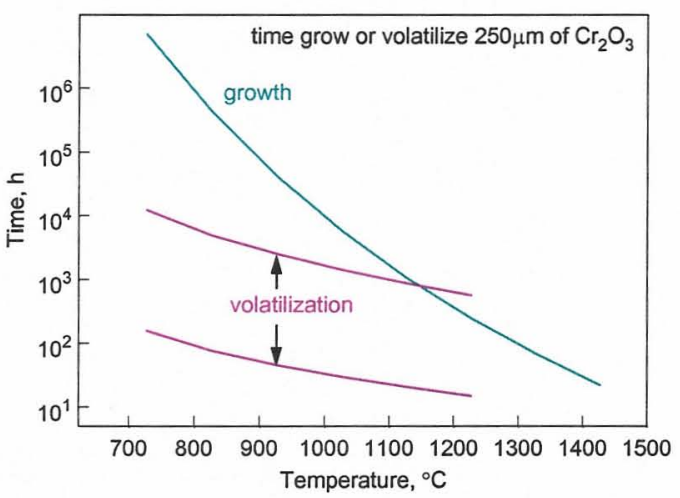

Fig. 4. Comparison of times to grow or volatilize a chromia scale of $250 \mu \mathrm{m}$ as a function of temperature. Volatility calculated for $\mathrm{P}=10$ atm and $\mathrm{v}=50 \mathrm{~m} / \mathrm{sec}$.

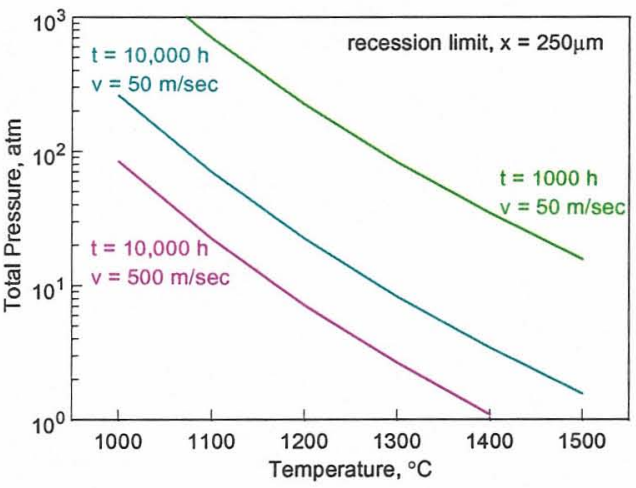

Fig. 6. Recession map for alumina volatility. Pressures and temperatures below the curves represent conditions with acceptable recession rates.

\section{Unanswered questions for chromia, silica and alumina volatility in high-temperature water vapor}

The chromia-water vapor system. Clearly, the biggest question in this system is the stability of the $\mathrm{CrO}_{2}(\mathrm{OH})_{2}(\mathrm{~g})$ species. The discrepancy between the Ebbinghaus [16], Gindorf [17], and IVTAN [18] data must be resolved before accurate chromia volatility predictions can be made. Weight change measurements of $304 \mathrm{~L}$ stainless due to oxidation/volatilization in water vaporcontaining environments by Asteman et al. [30] indicate that the Ebbinghaus data over-predict the volatility of chromia in water vapor. 
The silica-water vapor system. This system has been studied more thoroughly at NASA-Glenn, thus the higher familiarity with this system has raised more questions. First, and most importantly, at temperatures greater than $1400^{\circ} \mathrm{C}$, there is evidence that an $\mathrm{Si}-\mathrm{O}-\mathrm{H}$ species, in addition to $\mathrm{Si}(\mathrm{OH})_{4}$, contributes to silica volatility. Preliminary evidence suggests that $\mathrm{SiO}(\mathrm{OH})_{2}$ may explain these results [31]. The transpiration study by Hashimoto [22], however, showed no evidence of any species other than $\mathrm{Si}(\mathrm{OH})_{4}$ to temperatures as high as $1500^{\circ} \mathrm{C}$.

Similarly, silica volatility in fuel-rich conditions can not all be explained by $\mathrm{Si}(\mathrm{OH})_{4}(\mathrm{~g})$ formation. The additional volatility could be explained by an $\mathrm{Si}-\mathrm{O}-\mathrm{H}$ species with a higher water vapor partial pressure dependence than $\mathrm{Si}(\mathrm{OH})_{4}(\mathrm{~g})[32,33]$.

Differences in silica volatility were found for $\mathrm{SiC}$ and $\mathrm{Si}_{3} \mathrm{~N}_{4}$ in burner rig exposures [34] even after correction for volatilization of $\mathrm{CO}$ or $\mathrm{CO}_{2}$ and $\mathrm{N}_{2}$. One possible explanation is that the difference in emissivity of the materials results in different surface temperatures in the same environment.

Finally, Tedmon kinetics and volatilization limited by transport through a gas boundary layer no longer accurately describe the volatilization mechanism when gas velocities and the corresponding volatilization rates are so high that no silica is found on the surface of a silica-forming material. Bare $\mathrm{Si}_{3} \mathrm{~N}_{4}$ surfaces have been observed in turbine vane testing $[35,36]$. In this case, the volatilization and recession could be limited by oxide growth, or a completely different mechanism similar to active oxidation could be operative. A mechanism can be envisioned in which $\mathrm{SiC}$ or $\mathrm{Si}_{3} \mathrm{~N}_{4}$ volatilizes directly to $\mathrm{Si}(\mathrm{OH})_{4}$ without the formation of a solid silica intermediate step. The temperature dependence of such a process is expected to vary from that of the oxidation/volatilization process.

The alumina-water vapor system. Fairly good agreement exists between estimated data for $\mathrm{Al}(\mathrm{OH})_{3}(\mathrm{~g})$ formation, transpiration results for a mixture of calcium aluminate phases, weight loss of sapphire coupons, and volatility observed in a high pressure burner rig. The major shortcoming of the data for this system is that the existence of the $\mathrm{Al}(\mathrm{OH})_{3}(\mathrm{~g})$ species has not been confirmed experimentally by any technique, but only inferred from the pressure dependence of volatility. Preliminary mass spectrometry results have been obtained [37] for $\mathrm{Al}(\mathrm{OH})_{2}{ }^{+}$at $\mathrm{m} / \mathrm{e}=61 \mathrm{amu}$, a possible fragment of $\mathrm{Al}(\mathrm{OH})_{3}$, but more definitive evidence is required to confirm the identity of $\mathrm{Al}(\mathrm{OH})_{3}(\mathrm{~g})$.

\section{Summary}

The volatility of chromia, silica, and alumina in high-temperature water vapor has been discussed. Kinetic equations which describe both the oxidation and volatilization processes have been reviewed. Recession maps have been presented for each oxide-water vapor system which show pressure-temperature use ranges for a given recession limit. Recession rates have been compared to oxidation rates. Topics related to oxide volatility which require further understanding have been summarized. Finally, it has been shown that the severity of volatility increases in order for the alumina-, silica-, and chromia-water vapor systems.

\section{Acknowledgments}

The author would like to acknowledge N. Jacobson, E. Copland, D. Myers, J. Smialek, C. Robinson, and D. Fox for their contributions to this work. 


\section{References}

[1] E.J. Opila and N.S. Jacobson, p. 269 in Fundamental Aspects of High Temperature Corrosion, eds. D.A. Shores, R.A. Rapp, and P.Y. Hou, The Electrochemical Society, Inc., Pennington, NJ, 1997.

[2] C.S. Tedmon, Jr., J. Electrochem. Soc. 113 [8] 766 (1966).

[3] H. Hindam, D.P. Whittle, Ox. Met. 18 [5/6] 245 (1982).

[4] P. Kofstad, K.P. Lillerud, J. Electrochem. Soc. 127 [11] 2410 (1980).

[5] Y. Saito, T. Inoue, T. Maruyama, T. Amano, p. 191 in Proceedings JIMS-3 (1983): High

Temperature Corrosion Transaction of the Japan Institute of Metals, Vol. 24, Supplement.

[6] B.E. Deal, A.S. Grove, J. Appl. Phys. 36 [12] 3770 (1982).

[7] E.J. Opila, J. Am. Ceram. Soc. 82 [3] 625 (1999).

[8] E.J. Opila, R.C. Robinson, p. 398 in High Temperature Corrosion and Materials Chemistry, eds. M. McNallan, E. Opila, T. Maruyama, T. Narita, The Electrochemical Society, Inc., Pennington, NJ, 1999.

[9] D.J. Choi, D.B. Fischbach, W.D. Scott, J. Am. Ceram. Soc. 72 [7] 1118 (1989).

[10] F.S. Pettit, Trans. Met. Soc., AIME 239, 1296 (1967).

[11] T.A. Ramanarayanan, M. Raghavan, R. Petkovic-Luton, J. Electrochem. Soc. 131 [4] 923 (1984).

[12] R. Janakiraman, G.H. Meier, F.S. Pettit, Met. Mat. Trans A, 30A, 2906 (1999).

[13] E. Opila, N. Jacobson, D. Humphrey, T. Yoshi, K. Oda, p. 430 in High Temperature Corrosion and Materials Chemistry, eds. M. McNallan, E. Opila, T. Maruyama, T. Narita, The Electrochemical Society, Inc., Pennington, NJ, 1998.

[14] D.R. Gaskell, An Introduction to Transport Phenomena in Materials Engineering, Macmillan Publishing Company, New York, 1992.

[15] G.H. Geiger, D.R. Poirier, Transport Phenomena in Metallurgy, Addison-Wesley Publishing Company, Reading, MA, 1980.

[16] B.B. Ebbinghaus, Combus. Flame, 93, 119 (1993).

[17] C. Gindorf, K. Hilpert, L. Singheiser, p. 793 in Solid Oxide Fuel Cells, VII, eds. H. Yokokawa, S. Singhal, The Electrochemical Society, Pennington, NJ, 2001.

[18] IVTANTHERMO-A Thermodynamic Database and Software System for the Computer, eds. V.S. Yungman, V.A. Medvedev, I. V. Veits, G.A. Bergman, CRC Press and Begell House, Boca Raton, FL, 1993.

[19] M.W. Chase, Jr., C.A. Davies, J.R. Downey, Jr., D.J. Frurip, R.A. McDonald, A.N. Syverud, Eds., JANAF Thermochemical Tables, $3^{\text {rd }}$ Ed., American Chemical Society and

American Physical Society, New York (1989).

[20] L.V. Gurvich, I.V. Veyts, C.B. Alcock, Thermodynamic Properties of Individual Substances, Vol. 3, Begell House, Inc., New York, 1996.

[21] O.H. Krikorian, p. 481 in the Symposium on Engineering with Nuclear Explosives, 1970, unpublished.

[22] A. Hashimoto, Geochim. Cosmochim. Acta 56, 511 (1992).

[23] M.D. Allendorf, C.F. Melius, P. Ho, M.R. Zachariah, J. Phys. Chem. 99, 15285 (1995).

[24] E. Copland, D. Myers, E.J. Opila, N.S. Jacobson, p. 253 in High Temperature Corrosion and Materials Chemistry III, eds. M. McNallan, E. Opila, The Electrochemical Society, Inc., Pennington, NJ, 2001.

[25] E.J. Opila, R.E. Hann, Jr., J. Am. Ceram. Soc. 80 [1] 197 (1997).

[26] I. Yuri, T. Hisamatsu, GT2003-38886 in Proceedings of ASME Turbo Expo (Atlanta, Georgia, June 16-19, 2003) ASME, New York, 2003.

[27] M.D. Allendorf, C.F. Melius, B. Cosic, A. Fontijn, J. Phys. Chem. A, 106, 2629 (2002). 
[28] E.J. Opila, D.L. Myers, p. 535 in High Temperature Corrosion and Materials Chemistry IV, eds. E. Opila, P. Hou, T. Maruyama, B. Pieraggi, D. Shifler, E. Wuchina, The Electrochemical Society, Inc., Pennington, NJ, 2003.

[29] N.S. Jacobson, NASA TP-3162 (1992).

[30] H. Asteman, J.-E. Svensson, L.-G. Johansson, M. Norell, Ox. Met. 52 [1/2] 95 (1999).

[31] N.S. Jacobson, private communication

[32] E.J. Opila, J.L. Smialek, R.C. Robinson, D.S. Fox, N.S. Jacobson, J. Am. Ceram. Soc. 82 [7] 1826 (1999).

[33] A. Timoshkin, p. 262 in High Temperature Corrosion and Materials Chemistry III, eds. M. McNallan, E. Opila, The Electrochemical Society, Inc., Pennington, NJ, 2001.

[34] J.L. Smialek, R.C. Robinson, E.J. Opila, D.S. Fox, N.S. Jacobson, Adv. Comp. Mater. 8 [1] 33 (1999).

[35] E.J. Opila, J. Am. Ceram. Soc. 86 [8] 1238 (2003).

[36] M.K. Ferber, H.T. Lin, V. Parthasrathy, R.A. Wenglarz, GT-0661 in Proceedings of IGTI Conference (Munich, Germany, May 8-11, 2000) ASME, New York, 2000.

[37] D.L. Myers, N.S. Jacobson, private communication. 